\title{
Growth inhibition of Botrytis cinerea by compounds interfering with polyamine metabolism
}

\author{
Terence A. Smith, ${ }^{1 *}$ JaCqueline H. A. BarkeR $^{1}$ and Michel Jung ${ }^{2} \dagger$ \\ ${ }^{1}$ Research Station, Long Ashton, Bristol BS18 9AF, UK \\ ${ }^{2}$ Dow Elanco Ltd, Letcombe Regis, Wantage, Oxford, UK
}

(Received 13 November 1989; revised 25 January 1990; accepted 5 February 1990)

\begin{abstract}
Several inhibitors of ornithine and arginine decarboxylases reduced growth of the fungus Botrytis cinerea cultured on Czapek Dox agar. Of these, the most effective were difluoromethylornithine (DFMO), dehydromonofluoromethylornithine, difluoromethylarginine and dehydromonofluoromethylarginine. The growth inhibition due to $1 \mathrm{mM}$-DFMO could be partially reversed with $1 \mu \mathrm{M}$-putrescine. Other compounds causing significant reversal of DFMO-mediated growth inhibition included diaminopentane (cadaverine), diaminoheptane, spermidine, 7,7difluorospermidine, spermine, bis(2-aminoethyl)amine, 2-hydroxy-1,3-diaminopropane, monoacetylputrescine, butenediamine and aminoguanidine. Some compounds, which were relatively innocuous by themselves, increased growth inhibition due to DFMO. Notably effective compounds were methylacetylenicputrescine, aminooxyaminopropane, butynediamine, 2,2-difluoroputrescine, diacetylputrescine, methylglyoxal bis(guanylhydrazone), streptomycin, certain methylated amines, and cyclohexylamine and related compounds. Growth inhibition due to a homologous series of diguanidines $\left[\mathrm{NH}_{2} \mathrm{C}(=\mathrm{NH}) \mathrm{NH}\left(\mathrm{CH}_{2}\right)_{x} \mathrm{NHC}(=\mathrm{NH}) \mathrm{NH}_{2}\right]$ was also tested. These were especially effective when $x=12$, and when $x=5$ or 6 . In general, the results suggest that amino-acid-based inhibitors of ornithine decarboxylase have a greater permeability than amine-based inhibitors.
\end{abstract}

\section{Introduction}

It is now well established that in many organisms the natural polyamines, putrescine, spermidine and spermine, play a prominent part in mechanisms for the control of growth and development (Bachrach \& Heimer, 1988). Polyamine biosynthesis is greatly stimulated in rapidly growing tissues, and exogenous polyamines promote growth. Prevention of polyamine formation therefore offers a potential means of inhibiting growth. In animals, biosynthesis of the polyamines is initiated by the enzyme ornithine decarboxylase (ODC; EC 4.1.1.17), which forms putrescine. Several powerful enzyme-activated irreversible inhibitors of this enzyme have been discovered, notably difluoromethylornithine (DFMO). Recent work (Rajam \& Galston, 1985; Boyle et al., 1988; Rajam et al., 1989; Shapira et al., 1989;

$\dagger$ Present address: Merrell Dow Research Institute, Gruppo-Lepetit Centre, 21040 Gerenzano, VA Italy.

Abbreviations: ADC, arginine decarboxylase; ODC, ornithine decarboxylase; DFMA, difluoromethylarginine; $\triangle$ MFMA, dehydromonofluoromethylarginine; DFMO, difluoromethylornithine; $\triangle M F M O$, dehydromonofluoromethylornithine; ALP, 1-allenylputrescine; MAP, $R, R$-methylacetylenicputrescine.
Walters, 1989) has shown that this inhibitor can reduce fungal growth. In some of these studies, DFMO reduced the growth of plant pathogenic fungi, while having little apparent effect on the host plants. This is probably because higher plants have an alternative pathway [via arginine decarboxylase (ADC); EC 4 1.1.19] for putrescine biosynthesis which is thought to be unavailable to the fungus. This discovery has been the subject of two recent patents for the use of DFMO and similar ODC inhibitors as fungicides (Weinstein \& Galston, 1988; Carson \& McCann, 1988).

In the present work, the effect of several irreversible ODC and ADC inhibitors and various amines on the growth of Botrytis cinerea was investigated.

\section{Methods}

Growth. Botrytis cinerea Pers. (grey mould) was maintained on $25 \mathrm{ml}$ unsupplemented Czapek Dox medium containing $1.5 \%(\mathrm{w} / \mathrm{v})$ purified agar (Oxoid), in sealed $9 \mathrm{~cm}$ Petri dishes, lid down, at $23^{\circ} \mathrm{C}$ (optimum; Tan \& Epton, 1973), in the dark. Additions of all filter-sterilized chemicals $(0.2 \mu \mathrm{m}$ cellulose acetate membranes) were made when the temperature of the autoclaved medium had fallen to about $50^{\circ} \mathrm{C}$. Plates were inoculated with single $5 \mathrm{~mm}$ plugs cut from the leading edge of 3to 5-d-old colonies. Measurements of radial growth were taken $4.5 \mathrm{~d}$ 
after inoculation. Treatments were set up in duplicate, and two measurements were made on each plate at right-angles to each other. The statistical analysis, presented in the tables as the least significant difference (LSD) at the 0.05 level of probability, is based on a minimum of four measurements for each treatment (amine alone, DFMO alone, and amine + DFMO). The mycelial growth in the control (no treatment) had usually covered the surface of the agar after $6 \mathrm{~d}$. For calculation of radial growth, the plug diameter was subtracted from the radial measurement.

For growth in liquid medium, $100 \mathrm{ml}$ of Czapek Dox (Oxoid, CM95) was autoclaved in $250 \mathrm{ml}$ conical flasks and inoculated with $5 \mathrm{~mm}$ plugs, four to each flask. All filter-sterilized chemicals to be studied were added to the flasks containing autoclaved medium $\left(20^{\circ} \mathrm{C}\right)$. Flasks were incubated at $23^{\circ} \mathrm{C}$ on an orbital shaker (120 r.p.m.). Mycelia were separated from the medium by centrifugation $(23000 \mathrm{~g}, 20 \mathrm{~min})$, washed in water, and recentrifuged. Growth was estimated by fresh weight, and after drying in a vacuum over silica gel overnight at room temperature.

Chemicals. Free-base polyamines were converted to the hydrochlorides and crystallized from diethylether/ethanol/water mixtures. Other amines derived from cyclic hydrocarbons were obtained as the free bases and neutralized with hydrochloric acid in aqueous solution. Mono- and diacetylputrescine were synthesized by the method of Tabor et al. (1971). Since repeated crystallization of the monoacetylputrescine from 2-propanol failed to reduce the putrescine below $1 \%$, this was purified by high voltage paper electrophoresis at $1500 \mathrm{~V}$ for $2 \mathrm{~h}$ in 0.1 M-pyridine/acetic acid buffer ( $\mathrm{pH} 4.6$ ) on Whatman $3 \mathrm{MM}$ paper using ninhydrin for detection (Smith \& Marshall, 1988). The mobility relative to putrescine was 0.55 . The monoacetylputrescine was eluted with water and the volume reduced under vacuum at $50^{\circ} \mathrm{C}$. The putrescine content was then insignificant $(<0.01 \%)$.

In the Tables and the text, the sources of chemicals are designated by the letters shown in parentheses, as follows: Aldrich (A), Fluka (F), Koch-Light (KL), Lancaster Synthesis (L) and Sigma (S). Others were obtained or synthesized at Long Ashton (LA), or donated by Dow Elanco (D), Merrell Dow (MDL), KenoGard (K), Rhône-Poulenc (R), Dr W. G. Bardsley (B), or Dr N. Seiler (Se). All amino-acid-based inhibitors were racemic.

\section{Results and Discussion}

Reduction of growth by inhibitors of $O D C$ and $A D C$, and its reversal by amines

Considerable growth reduction was found on testing some of the irreversible inhibitors of ODC and ADC. The best were DFMO, $\triangle$ MFMO, DFMA and $\triangle$ MFMA (Table 1). However, MAP, which is a particularly effective enzyme-activated inhibitor of ODC in rat prostate, Trypanosoma brucei brucei (Bey et al., 1987) and Botrytis cinerea (Smith et al., 1990; M. Goosey, personal communication) appeared to produce a relatively small reduction in growth (Table 1). ALP, which is similarly known as an efficient inhibitor of ODC (Bey et al., 1987), was likewise comparatively ineffective in causing reduction of Botrytis growth. DFMA and $\triangle$ MFMA do not inhibit Botrytis ODC in vitro (Smith et al., 1990) and ODC inhibition cannot therefore explain the growth reduction found with the arginine analogues. There are several possible reasons for this anomaly. (1) Putrescine could be formed additionally via an ADC in Botrytis, as found in certain other fungi (Khan \& Minocha, 1989). The arginine analogues may be partially hydrolysed by arginase to DFMO and $\triangle \mathrm{MFMO}$ respectively, thus inhibiting both ODC and ADC. (2) The arginine analogues may inhibit arginase, thus reducing the availability of free ornithine. (3) It is also possible that the arginine analogues are activated in protein synthesis in place of arginine.

Growth inhibition due to DFMO could be readily reversed in the presence of $1 \mathrm{~mm}$-putrescine. Measuring growth in liquid culture by both fresh and dry weight, 1 mM-DFMO inhibited growth to $<10 \%$ of the control, and this was fully reversed by putrescine at $1 \mathrm{mM}$. Putrescine alone appeared to stimulate growth by up to $50 \%$ in liquid culture, but in agar, putrescine by itself had no significant effect on the growth of $B$. cinerea (Fig. 1). However, even $1 \mu \mathrm{M}$ caused about $50 \%$ reversal of the inhibition due to DFMO at $1 \mathrm{mM}$, and $10 \mu \mathrm{M}$ restored growth fully. For this reason it is important to use a medium containing no contaminating di- or polyamines when assessing the efficiency of potential inhibitors of ODC. The fact that only small amounts of putrescine are able to reverse the DFMO-mediated growth inhibition explains the slow reduction found in the presence of DFMO. Only after the endogenous polyamines have been diluted will they become growth limiting. This probably also explains the relative lack of effect of DFMO on spore germination (data not shown) and also noted by Trione et al. (1988) for spores of Tilletia.

In a homologous series of diamines, putrescine $\left(\mathrm{C}_{4}\right)$ was the most effective in causing this reversal (Fig. 1), with cadaverine $\left(\mathrm{C}_{5}\right)$ about $30 \%$ as efficient. In addition to these diamines, other analogous compounds were found to reverse the growth inhibitory effects of DFMO (Table 2). Predictably, these included spermidine and spermine, which are well established as primary metabolites of putrescine. bis(2-Aminoethyl)amine, an analogue of cadaverine, also showed some reversal, as did butenediamine and difluorospermidine. Diaminoheptane $\left(\mathrm{C}_{7}\right)$ was considerably more effective than the $\mathrm{C}_{6}$ or $\mathrm{C}_{8}$ diamines (Fig. 1), possibly as its length corresponds approximately to that of spermidine. Although diaminopropane was ineffective (Fig. 1), 2-hydroxydiaminopropane showed significant reversal (Table 2). In the absence of DFMO significant reduction in growth was caused by the $\mathrm{C}_{8}$ and $\mathrm{C}_{12}$ diamines (Fig. 1).

Early attempts in the present work to reverse DFMO inhibition with monoacetylputrescine, although successful, were confused by the residual putrescine in the preparation, which was difficult to remove by repeated crystallization. However, putrescine-free monoacetylputrescine purified by preparative electrophoresis still 
Table 1. Effect of $O D C$ and ADC inhibitors in the presence or absence of DFMO on growth of $B$. cinerea

Inhibitors and DFMO (MDL 71782) were present at $1 \mathrm{mM}$. Radial growth on Czapek Dox agar was measured after $4.5 \mathrm{~d}$ at $23^{\circ} \mathrm{C}$; values are given as percentages of the relevant controls (no compounds added). $\mathrm{LSD}_{0.05}$, least significant difference at the 0.05 level of probability.

\begin{tabular}{|c|c|c|c|c|}
\hline \multirow[b]{2}{*}{ Inhibitor } & \multicolumn{3}{|c|}{ Growth (\% control) } & \multirow[b]{2}{*}{$\mathrm{LSD}_{0.05}$} \\
\hline & $\begin{array}{l}\text { Inhibitor } \\
\text { alone }\end{array}$ & $\begin{array}{l}\text { DFMO } \\
\text { alone }\end{array}$ & $\begin{array}{l}\text { Inhibitor } \\
+ \text { DFMO }\end{array}$ & \\
\hline 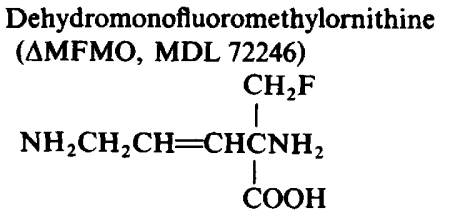 & 28 & 22 & 21 & 6 \\
\hline $\begin{array}{l}\text { 1-Allenylputrescine } \\
\text { (ALP, MDL 72451) }\end{array}$ & 91 & 22 & 31 & 6 \\
\hline \multicolumn{5}{|l|}{$\begin{array}{r}\mathrm{CH}=\mathrm{C}=\mathrm{CH}_{2} \\
\stackrel{!}{\mathrm{C}} \mathrm{NNH}_{2}\end{array}$} \\
\hline $\begin{array}{l}R, R \text {-Methylacetylenicputrescine } \\
\text { (MAP, MDL 72175) }\end{array}$ & 87 & 26 & 15 & 11 \\
\hline $\begin{array}{cc}\mathrm{CH}_{3} & \mathrm{C} \equiv \mathrm{CH} \\
\stackrel{\mid}{\mathrm{C}} & \stackrel{\mathrm{C}}{\mathrm{C}}\left(\mathrm{CH}_{2}\right)_{2}\end{array}$ & & & & \\
\hline $\begin{array}{l}\text { Difluoromethylarginine } \\
\text { (DFMA, MDL 71897) }\end{array}$ & 7 & 12 & 7 & 3 \\
\hline $\begin{array}{cc} & \mathrm{CF}_{2} \mathrm{H} \\
\mathrm{NH}_{2} \mathrm{CNH}\left(\mathrm{CH}_{2}\right)_{3} \mathrm{CNH}_{2} & \stackrel{\mathrm{N}}{\mathrm{N}} \\
\mathrm{NH} & \mathrm{COOH}\end{array}$ & & & & \\
\hline $\begin{array}{l}\text { Dehydromonofluoromethylarginine } \\
\text { (AMFMA, MDL 27383) }\end{array}$ & 22 & 26 & 19 & 11 \\
\hline 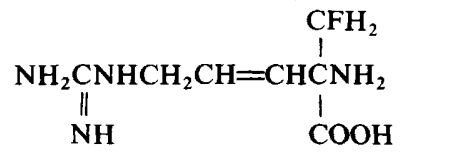 & & & & \\
\hline
\end{tabular}

reversed the DFMO-mediated growth inhibition. This may therefore result from the presence of a deacetylase in $B$. cinerea, an enzyme which is known to occur in some fungi (Haywood \& Large, 1986). Diaminobutanone and agmatine, although structurally similar to putrescine, did not significantly reverse the growth reduction caused by DFMO (results not shown). Moreover, 1 mM-diaminobutanone permitted growth at $73 \%$ of the control, although this amine is a very effective competitive inhibitor of ODC in Aspergillus nidulans (Stevens \& McKinnon, 1977). The reversal found with aminoguanidine (Table 2) may be explained by the inhibition of enzymes degrading putrescine and the polyamines (Seiler et al., 1983). It is possible that the reversal of growth inhibition by the diand polyamines could be explained, at least in part, by competition of the amines with DFMO for transport sites on the cell membranes. Such systems have been demonstrated in bacteria and yeast (Massart, 1948; Elferink, 1975).

\section{Synergism of DFMO-mediated growth inhibition}

Several compounds were found which, although relatively innocuous alone, caused a considerable increase in the DFMO-mediated growth inhibition (Table 3). Aminooxyaminopropane is a potent competitive inhibitor of mammalian and bacterial ODC and of mammalian spermidine synthase (Hyvonen et al., 1988). It was not an effective inhibitor of growth of $B$. cinerea, possibly because it is excluded from the cell in the absence of DFMO; this may also be true for MAP (Table 1). The putrescine analogue ALP, which is known to have only 


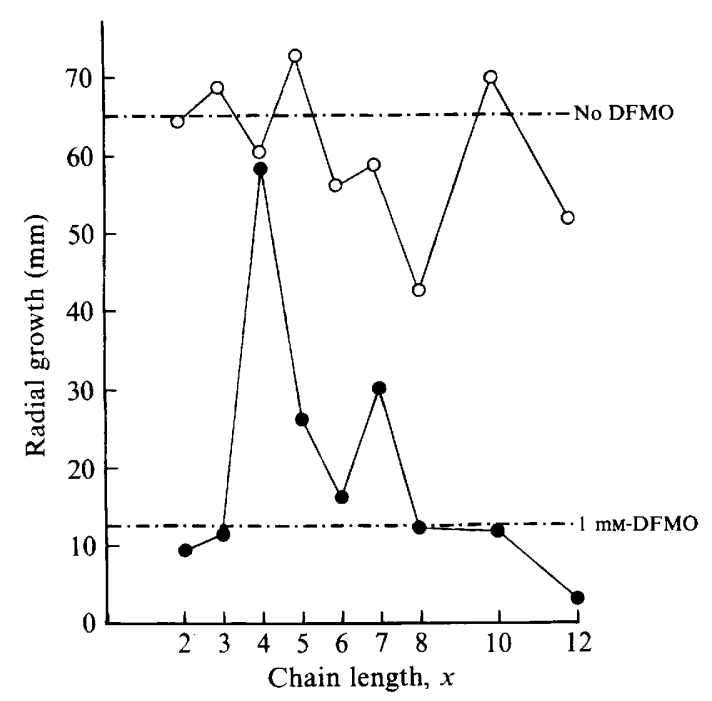

Fig. 1. Effect of a homologous series of diamines $\left[\mathrm{NH}_{2}\left(\mathrm{CH}_{2}\right)_{x} \mathrm{NH}_{2}\right]$, all at $1 \mathrm{mM}$, on the DFMO-mediated inhibition of growth of $B$. cinerea. Radial growth on Czapek Dox agar was measured after $4.5 \mathrm{~d}$ at $23^{\circ} \mathrm{C}$. Mean radial values with $(\bigcirc)$ and without $(O) 1 \mathrm{mM}$-DFMO are given. -.-.-., Control values. $\mathrm{LSD}_{0.05}, 10 \mathrm{~mm}$. weak ODC inhibitory properties, albeit in other organisms (Bey et al., 1987), showed no synergism with DFMO. Notable compounds showing synergism with DFMO included several methylated polyamines. In other work, DFMO-mediated polyamine depletion of SV-3T3 cells caused growth inhibition, which could be reversed by several chain-methylated polyamine derivatives. However, unlike the present work, in no case was growth in DFMO shown to be further reduced in the presence of the spermidine analogues (Nagarajan et al., 1988).

Other putrescine analogues showing a synergistic effect with DFMO in the present work included butynediamine (Table 3), in contrast to the behaviour of butenediamine (Table 2), which reversed DFMO inhibition. Also difluoroputrescine (Sarhan et al., 1987), unlike difluorospermidine, enhanced DFMO inhibition (Table 3).

Cyclohexylamine and analogous compounds, which include cyclopentylamine, cycloheptylamine, 4-methylcyclohexylamine and cyclohexanemethylamine also acted as synergists for DFMO-mediated growth reduction

Table 2. Amines capable of antagonizing the growth inhibition of B. cinerea due to DFMO

Amines and DFMO were present at $1 \mathrm{mM}$. Radial growth on Czapek Dox agar was measured after $4.5 \mathrm{~d}$ at $23^{\circ} \mathrm{C}$; values are given as percentages of the relevant controls (no compounds added). Letters in parentheses denote the sources of the chemicals (see Methods). LSD $_{0.05}$, least significant difference at the 0.05 level of probability.

\begin{tabular}{|c|c|c|c|c|}
\hline \multirow[b]{2}{*}{ Amine added } & \multicolumn{3}{|c|}{ Growth $(\%$ control $)$} & \multirow[b]{2}{*}{ LSD $_{0.05}$} \\
\hline & $\begin{array}{l}\text { Amine } \\
\text { alone }\end{array}$ & $\begin{array}{l}\text { DFMO } \\
\text { alone }\end{array}$ & $\begin{aligned} & \text { Amine } \\
+ & \text { DFMO }\end{aligned}$ & \\
\hline $\begin{array}{l}\text { Putrescine (F) } \\
\mathrm{NH}_{2}\left(\mathrm{CH}_{2}\right)_{4} \mathrm{NH}_{2}\end{array}$ & 90 & 33 & 102 & 10 \\
\hline $\begin{array}{l}\text { Spermidine (F) } \\
\mathrm{NH}_{2}\left(\mathrm{CH}_{2}\right)_{3} \mathrm{NH}\left(\mathrm{CH}_{2}\right)_{4} \mathrm{NH}_{2}\end{array}$ & 92 & 40 & 83 & 11 \\
\hline $\begin{array}{l}\text { Spermine (F) } \\
\mathrm{NH}_{2}\left(\mathrm{CH}_{2}\right)_{3} \mathrm{NH}\left(\mathrm{CH}_{2}\right)_{4} \mathrm{NH}\left(\mathrm{CH}_{2}\right)_{3} \mathrm{NH}_{2} \\
\text { bis }(2-\mathrm{Aminoethyl}) \text { amine }(\mathrm{F})\end{array}$ & 97 & 40 & 88 & 11 \\
\hline $\begin{array}{l}\mathrm{NH}_{2}\left(\mathrm{CH}_{2}\right)_{2} \mathrm{NH}\left(\mathrm{CH}_{2}\right)_{2} \mathrm{NH}_{2} \\
\text { 2-Hydroxy-1,3-diaminopropane (S) }\end{array}$ & 93 & 31 & 43 & 10 \\
\hline $\begin{array}{l}\mathrm{NH}_{2} \mathrm{CH}_{2} \mathrm{CH}(\mathrm{OH}) \mathrm{CH}_{2} \mathrm{NH}_{2} \\
\text { 1,4-Butenediamine }(\mathrm{Se})\end{array}$ & 94 & 19 & 35 & 16 \\
\hline $\begin{array}{l}\mathrm{NH}_{2} \mathrm{CH}_{2} \mathrm{CH}=\mathrm{CHCH}_{2} \mathrm{NH}_{2} \\
\text { Aminoguanidine (S) }\end{array}$ & 60 & 34 & 55 & 6 \\
\hline $\begin{array}{l}\mathrm{NH}_{2} \mathrm{NHC}(=\mathrm{NH}) \mathrm{NH}_{2} \\
\text { Monoacetylputrescine (see text) }\end{array}$ & 96 & 35 & 59 & 11 \\
\hline $\begin{array}{l}\mathrm{CH}_{3} \mathrm{C}(=\mathrm{O}) \mathrm{NH}\left(\mathrm{CH}_{2}\right)_{4} \mathrm{NH}_{2} \\
\text { 7,7-Difluorospermidine (MDL 72748) }\end{array}$ & 102 & 37 & 86 & 5 \\
\hline $\mathrm{NH}_{2} \mathrm{CH}_{2} \mathrm{CF}_{2}\left(\mathrm{CH}_{2}\right)_{2} \mathrm{NH}\left(\mathrm{CH}_{2}\right)_{3} \mathrm{NH}_{2}$ & 109 & 34 & 50 & 6 \\
\hline
\end{tabular}


Table 3. Basic compounds that enhance the growth inhibition of B. cinerea due to DFMO

Basic compounds and DFMO were present at $1 \mathrm{mM}$. Radial growth on Czapek Dox agar was measured after $4.5 \mathrm{~d}$ at $23^{\circ} \mathrm{C}$; values are given as percentages of the relevant controls (no compounds added). Letters in parentheses denote the sources of the chemicals (see Methods). $\mathrm{LSD}_{0.05}$, least significant difference at the 0.05 level of probability.

\begin{tabular}{|c|c|c|c|c|}
\hline \multirow[b]{2}{*}{ Basic compound added } & \multicolumn{3}{|c|}{ Growth $(\%$ control $)$} & \multirow[b]{2}{*}{$\operatorname{LSD}_{0} \cdot 05$} \\
\hline & $\begin{array}{l}\text { Amine } \\
\text { alone }\end{array}$ & $\begin{array}{l}\text { DFMO } \\
\text { alone }\end{array}$ & $\begin{aligned} & \text { Amine } \\
+ & \text { DFMO }\end{aligned}$ & \\
\hline $\begin{array}{l}\text { 1-Dimethyl-1,3-diaminopropane (LA) } \\
\left(\mathrm{CH}_{3}\right)_{2} \mathrm{~N}\left(\mathrm{CH}_{2}\right)_{3} \mathrm{NH}_{2}\end{array}$ & 104 & 37 & 11 & 10 \\
\hline $\begin{array}{l}\text { Aminooxyaminopropane (D) } \\
\mathrm{NH}_{2} \mathrm{O}\left(\mathrm{CH}_{2}\right)_{3} \mathrm{NH}_{2}\end{array}$ & 72 & 34 & 19 & 6 \\
\hline $\begin{array}{l}\text { Butynediamine (Se) } \\
\mathrm{NH}_{2} \mathrm{CH}_{2} \mathrm{C} \equiv \mathrm{CCH}_{2} \mathrm{NH}_{2}\end{array}$ & 114 & 34 & 27 & 6 \\
\hline $\begin{array}{l}\text { Diacetylputrescine (see text) } \\
\mathrm{CH}_{3}(\mathrm{C}=\mathrm{O}) \mathrm{NH}\left(\mathrm{CH}_{2}\right)_{4} \mathrm{NH}(\mathrm{C}=\mathrm{O}) \mathrm{CH}_{3}\end{array}$ & 101 & 35 & 19 & 11 \\
\hline $\begin{array}{l}\text { Tetramethylputrescine (A) } \\
\left(\mathrm{CH}_{3}\right)_{2} \mathrm{~N}\left(\mathrm{CH}_{2}\right)_{4} \mathrm{~N}\left(\mathrm{CH}_{3}\right)_{2}\end{array}$ & 107 & 31 & 11 & 10 \\
\hline $\begin{array}{c}\text { Pentamethylspermidine (LA) } \\
\left(\mathrm{CH}_{3}\right)_{2} \mathrm{~N}\left(\mathrm{CH}_{2}\right)_{3} \mathrm{~N}\left(\mathrm{CH}_{2}\right)_{4} \mathrm{~N}\left(\mathrm{CH}_{3}\right)_{2} \\
\mathrm{CH}_{3}\end{array}$ & 108 & 40 & 19 & 11 \\
\hline $\begin{array}{l}\text { 2,2-Difluoroputrescine (MDL 72720) } \\
\mathrm{NH}_{2} \mathrm{CH}_{2} \mathrm{CF}_{2}\left(\mathrm{CH}_{2}\right)_{2} \mathrm{NH}_{2}\end{array}$ & 101 & 32 & 17 & 7 \\
\hline $\begin{array}{l}\text { Pentamethonium (L) } \\
\left(\mathrm{CH}_{3}\right)_{3} \mathrm{~N}^{+}\left(\mathrm{CH}_{2}\right)_{5} \mathrm{~N}^{+}\left(\mathrm{CH}_{3}\right)_{3}\end{array}$ & 110 & 35 & 23 & 5 \\
\hline $\begin{array}{l}\text { Hexamethonium (S) } \\
\left(\mathrm{CH}_{3}\right)_{3} \mathrm{~N}^{+}\left(\mathrm{CH}_{2}\right)_{6} \mathrm{~N}^{+}\left(\mathrm{CH}_{3}\right)_{3}\end{array}$ & 83 & 35 & 22 & 6 \\
\hline $\begin{array}{l}\text { Decamethonium (S) } \\
\left(\mathrm{CH}_{3}\right)_{3} \mathrm{~N}^{+}\left(\mathrm{CH}_{2}\right)_{10} \mathrm{~N}^{+}\left(\mathrm{CH}_{3}\right)_{3}\end{array}$ & 91 & 35 & 20 & 5 \\
\hline $\begin{array}{ccc}\text { Methylglyoxal bis(guanylhydrazone) (A) } \\
\begin{array}{ccc}\mathrm{NH}_{2} \mathrm{CNHN}= \\
\| & \mathrm{CCH}=\mathrm{NNHCNH}_{2} \\
\mathrm{NH} & \mathrm{CH}_{3} & \| \\
\mathrm{NH}\end{array}\end{array}$ & 58 & 40 & 16 & 11 \\
\hline Streptomycin (S) & 98 & 35 & 15 & 11 \\
\hline
\end{tabular}

(Table 4). Cyclohexylamine and related compounds inhibit spermidine synthase (Porta et al., 1983; Shirahata et al., 1988; Bitonti \& McCann, 1987) and it is possible that this synergism is related to their abilities to inhibit this enzyme. A similar augmentation of DFMO-mediated inhibition by cyclohexylamine has been found with the yeast Candida (Pfaller et al., 1988).

cis-1,4-Cyclohexanediamine (Sarhan et al., 1987) was not an effective growth inhibitor, despite its structural similarity to putrescine and to cyclohexylamine, the established inhibitor of spermidine synthase.

A possible explanation for the increased growth inhibition caused by some of these compounds in the presence of DFMO may lie in the broad specificity of a membrane-based diamine uptake system, which becomes activated when endogenous putrescine is depleted. A system with some of these characteristics has been found in Ehrlich ascites carcinoma cells (AlhonenHongisto et al., 1980) and in Neurospora (Davis \& Ristow, 1989). The putrescine analogues present in the medium could then be accumulated to growth inhibitory levels. This suggests the possibility of increasing the growth reduction due to the ODC inhibitors by causing accumulation of inhibitory amines applied simultaneously, and may provide a new approach to the development of fungicides based on the inhibition of ODC.

Combination of DFMO with other basic chemotherapeutic agents showed a strong synergism in the treatment of trypanosomiasis, though the mechanism for this is still not clear (Tyms et al., 1988). It would be of interest to determine experimentally whether access of inhibitory amines into the cell is enhanced by DFMO treatment. Alternatively, the further depletion of the natural 
Table 4. Effect of cyclohexylamine and some of its analogues in the presence or absence of DFMO on growth of $B$. cinerea

Amines and DFMO were present at $1 \mathrm{mM}$. Radial growth on Czapek Dox agar was measured after $4.5 \mathrm{~d}$ at $23^{\circ} \mathrm{C}$; values are given as percentages of the relevant controls (no compounds added). Letters in parentheses denote the sources of the chemicals (see Methods). LSD 0.05 , least significant difference at the 0.05 level of probability.

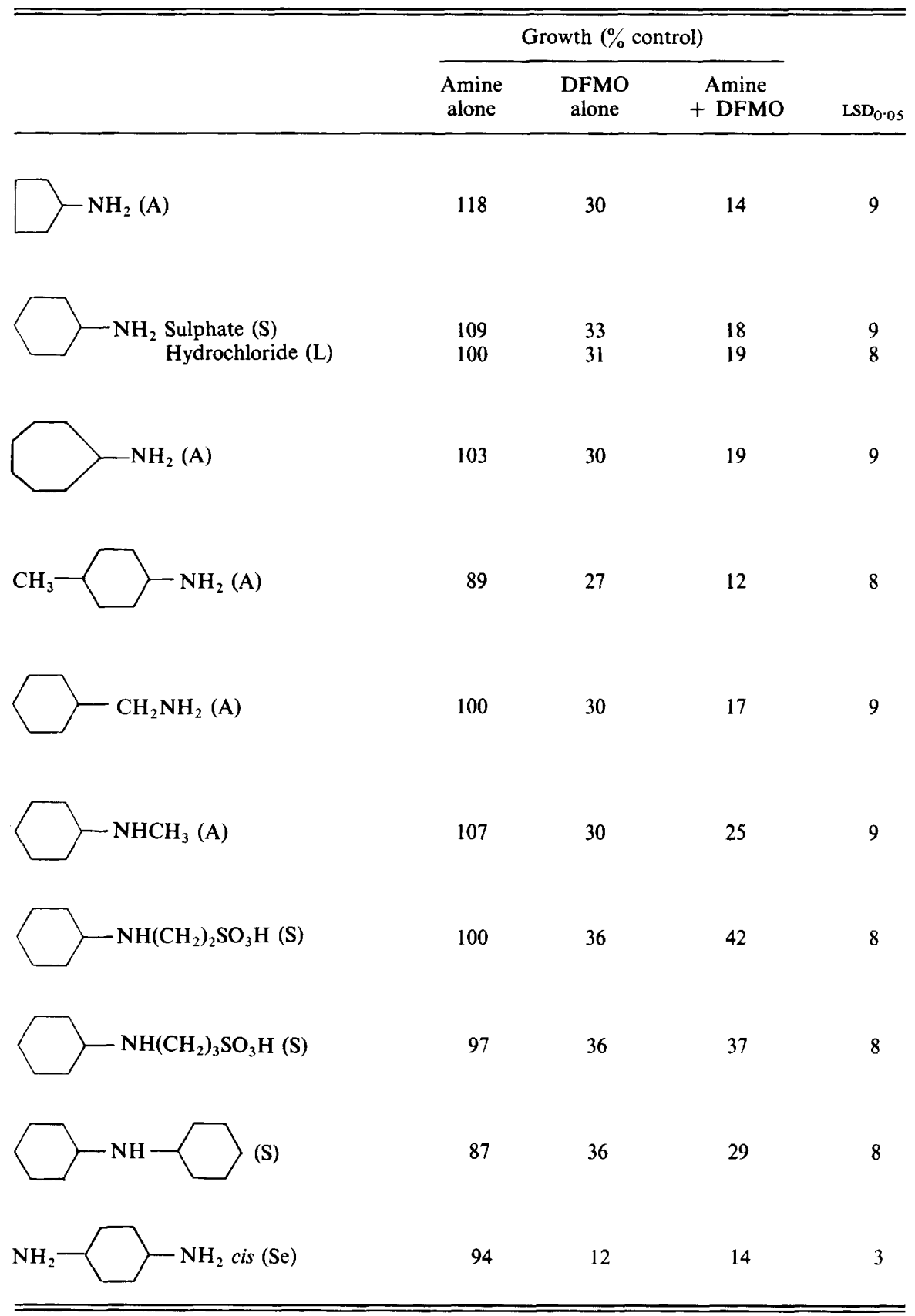

polyamines by their synthetic analogues might be the result of metabolic intervention. However, changes in access to subcellular particles may be difficult to quantify. With the present state of knowledge, it is not easy to define the precise mechanism of the synergism.
Compounds for which growth-inhibitory properties are independent of DFMO

The effect of several known fungicides on DFMOmediated growth inhibition was also tested. Befran 


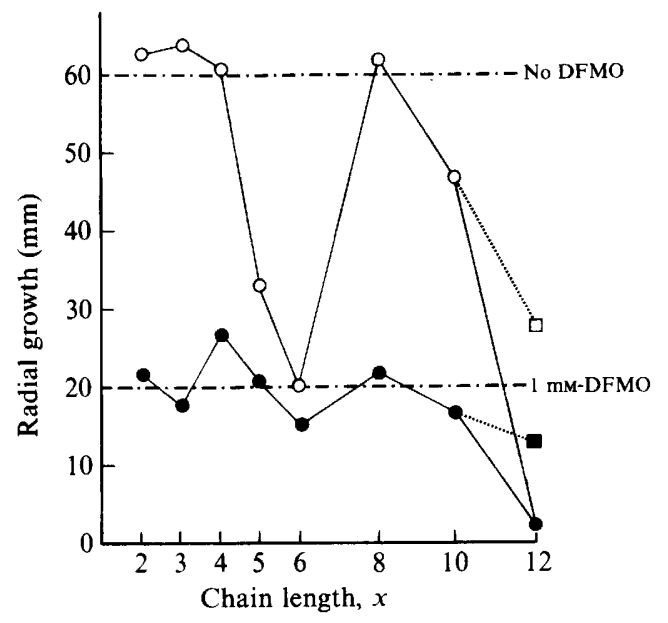

Fig. 2. Effect of a homologous series of diguanidines $\left[\mathrm{NH}_{2} \mathrm{C}(=\mathrm{NH}) \mathrm{NH}\left(\mathrm{CH}_{2}\right)_{x} \mathrm{NHC}(=\mathrm{NH}) \mathrm{NH}_{2}\right]$ on growth of $B$. cinerea. Radial growth was measured after $4.5 \mathrm{~d}$ at $23^{\circ} \mathrm{C}$. Mean radial values with $(\bigcirc)$ and without $(O) 1 \mathrm{mM}$ DFMO are given. All diguanidines were tested at $1 \mathrm{~mm}$ except when $x=12$, when both $0.1 \mathrm{mM}(\square, \square)$ and $1 \mathrm{~mm}$ were used. .-.-.-, Control values. LSD $_{0.05}, 6 \mathrm{~mm}$.

[guazatine (K)] (Hudson et al., 1986) was fully inhibitory at $1 \mathrm{mM}$ in the presence or absence of DFMO. At $0 \cdot 1 \mathrm{mM}-$ Befran, growth was reduced to $21 \%$ of the control, but no significant interaction was found with DFMO. Carbendazim (LA), a tubulin-binding fungicide (Dekker, 1984), was fully inhibitory at $0.1 \mathrm{mM}$, and at $1 \mu \mathrm{M}$ it showed significant synergism with DFMO. Metalaxyl (D), a fungicide interfering with RNA polymerase (Davidse, 1984) which is not effective against the Deuteromycotina, showed no interaction with DFMO.

Compounds which were particularly active as growth inhibitors per se included (with concentrations and growth as a percentage of the control given in parentheses) diaminodipropylamine (KL) $(1 \mathrm{mM}, 15 \%)$ and $N$ decylamino-1,3-diaminopropane (LA) (1 mM, 4\%), previously studied by Brown \& Woodcock (1973). Pentamidine isethionate (R) $(1 \mathrm{mM}, 13 \%)$ and Berenil (S) ( $1 \mathrm{mM}, 10 \% ; 0.1 \mathrm{~mm}, 49 \%$ ) are known polybasic antiprotozoan agents (Bitonti et al., 1986).

The effect on growth of a homologous series of diguanidines was also tested (Fig. 2), since these dibasic compounds are structurally similar to the diamines. Greatest inhibition was shown with a methylene chain length $(x)$ of 12 units, but inhibition was also found with $x=5$ and 6 . DFMO-mediated growth inhibition was not reversed, other than when $x=4$, which was just significant. The inhibitory effect of long-chain diguanidines on fungal growth has been noted earlier (reviewed by Hudson et al., 1986).
Other workers (Porter \& Bergeron, 1988; Casero et al., 1989) have found that some amine analogues are able to suppress ODC activity by utilizing the mechanism for feedback inhibition by the natural polyamines; these same analogues are then able to interfere with polyamine-requiring processes, thereby reducing growth. A notable example of these polyamine analogues is bis-[(3phenylmethyl)aminopropyll-1,7-diaminoheptane (MDL 27695) (Bitonti et al., 1989a,b). This was a very effective inhibitor of the radial growth of Botrytis at $1 \mathrm{~mm}(0 \%)$, though at $0.1 \mathrm{~mm}$ it had surprisingly little activity $(85 \%)$, and showed no synergism with DFMO.

\section{Hypothesis to account for the results}

In conclusion, it seems likely that amino-acid-based ODC inhibitors have relatively free access to the fungal cells, while amine-based inhibitors (e.g. MAP or aminooxyaminopropane) may be unable to enter. In the presence of DFMO, an exclusion mechanism could be inactivated and uptake of the putrescine analogues may even be facilitated, resulting in synergism of the growth reduction. This additional growth loss may be due to inhibition of other pathways of polyamine biosynthesis, as seems likely for cyclohexylamine and its analogues, or even to a disruption of the mechanisms which putrescine and the polyamines control (e.g. nucleic acid and protein synthesis); this could be the explanation for the synergism shown by some of the di- and polyamine analogues (e.g. the methylated and fluorinated amines).

The authors are very grateful to Dr D. W. Hollomon and Mrs Carolyn James of Long Ashton Research Station, to Dr W. G. Bardsley of St Mary's Hospital, Manchester, to Mr N. H. Kimberley, of RhônePoulenc, Dagenham, Essex, to Dr Inger Lagerlund of KenoGard, Stockholm, Sweden, and to Dr P. P. McCann and Dr N. Seiler of Merrell Dow, respectively in Cincinnati, Ohio, USA, and Strasbourg, France, for the donation of chemicals, and to Dr R. S. T. Loeffler and $\mathrm{Mr}$ M. Lewis for characterization. We are also indebted to Dr P. Brain of Long Ashton for his help with the statistics, and to many others at Long Ashton and Dow for advice on fungal culture techniques. We are especially grateful to Dow Elanco Ltd. for financing the work in its entirety.

\section{References}

Alhonen-Hongisto, L., Seppänen, P. \& JÄnNe, J. (1980). Intracellular putrescine and spermidine deprivation induces increased uptake of the natural polyamines and methylglyoxal bis(guanylhydrazone). Biochemical Journal 192, 941-945.

Bachrach, U. \& Heimer, Y. M. (eds) (1988). The Physiology of Polyamines. Boca Raton, Florida: CRC Press.

BEY, P., DANZIN, C. \& JUNG, M. (1987). Inhibition of basic amino acid decarboxylases involved in polyamine biosynthesis. In Inhibition of Polyamine Metabolism, pp. 1-31. Edited by P. P. McCann, A. E. Pegg \& A. Sjoerdsma. Orlando: Academic Press. 
Bitonti, A. J. \& MCCaNN, P. P. (1987). Inhibition of polyamine biosynthesis in microorganisms. In Inhibition of Polyamine Metabolism, pp. 259-275. Edited by P. P. McCann, A. E. Pegg \& A. Sjoerdsma. Orlando: Academic Press.

Bitonti, A. J., Dumont, J. A. \& McCanN, P. P. (1986). Characterization of Trypanosoma brucei brucei $S$-adenosyl-L-methionine decarboxylase and its inhibition by Berenil, pentamidine and methylglyoxal bis(guanylhydrazone). Biochemical Journal 237, 685-689.

Bitonti, A. J., Bush, T. L. \& MCCANN, P. P. (1989a). Regulation of polyamine biosynthesis in rat hepatoma (HTC) cells by a bisbenzyl polyamine analogue. Biochemical Journal 257, 769-774.

Bitonti, A. J., Dumont, J. A., Bush, T. L., Edwards, M. L., Stemerick, D. M., MCCanN, P. P. \& SJoerdsma, A. (1989b). Bis(benzyl)polyamine analogs inhibit the growth of chloroquineresistant human malaria parasites (Plasmodium falciparum) in vitro, and in combination with $\alpha$-difluoromethylornithine cure murine malaria. Proceedings of the National Academy of Sciences of the United States of America 86, 651-655.

Boyle, S. M., SRIRANGanathan, N. \& Cordes, D. (1988). Susceptibility of Microsporum and Trichophyton species to suicide inhibitors of polyamine biosynthesis. Journal of Medical and Veterinary Mycology 26, 227-235.

Brown, D. \& Woodcock, D. (1973). Fungicidal activity and chemical constitution. XXI. The fungitoxicity of aliphatic polyamines. Pesticide Science 4, 485-490.

Carson, C. M. \& MCCanN, P. P. (1988). Method of controlling phytopathogenic fungus. US Patent 4760091 (Chemical Abstracts 109, 185468).

Casero, R. A., Ervin, S. J., Celano, P., Baylin, S. B. \& Bergeron, R. J. (1989). Differential response to treatment with the bis(ethyl)polyamine analogues between human small cell lung carcinoma and undifferentiated large cell lung carcinoma in culture. Cancer Research 49, 639-643.

Davidse, L. C. (1984). Antifungal activity of acylalanine fungicides and related chloroacetanilide herbicides. In Mode of Action of Antifungal Agents, pp. 239-255. Edited by A. P. J. Trinci \& J. F. Ryley. Cambridge: Cambridge University Press.

DAvIS, R. H. \& RisTow, J. L. (1989). Uptake, intracellular binding and excretion of polyamines during growth of Neurospora crassa. Archives of Biochemistry and Biophysics 271, 315-322.

DEKKER, J. (1984). Development of resistance to antifungal agents. In Mode of Action of Antifungal Agents, pp. 89-111. Edited by A. P. J. Trinci \& J. F. Ryley. Cambridge: Cambridge University Press.

ELFERINK, J. G. R. (1975). Influence of spermine on some membranedisturbing actions. Zeitschrift für Naturforschung 30c, 117-119.

HAYwOOD, G. W. \& LARGE, P. J. (1986). 4-Acetamidobutyrate deacetylase in the yeast Candida boidinii grown on putrescine or spermidine as sole nitrogen source and its probable role in polyamine catabolism. Journal of General Microbiology 132, 7-14.

Hudson, H. R., Ojo, I. A. O. \& Pianka, M. (1986). Guanidines with antifungal (and antibacterial) activity - a review. International Pest Control, pp. 148-155.

Hyvonen, T., Alakuijala, L., Andersson, L., Khomutov, A. R., Khomutov, R. M. \& Eloranta, T. O. (1988). 1-Aminooxy-3aminopropane reversibly prevents the proliferation of cultured baby hamster kidney cells by interfering with polyamine synthesis. Journal of Biological Chemistry 263, 11138-11144.

Khan, A. J. \& Minocha, S. C. (1989). Biosynthetic arginine decarboxylase in phytopathogenic fungi. Life Sciences 44, 12151222.

MasSART, L. (1948). Antagonism between basic compounds (spermine, streptomycin) and basic bactericidal substances. Nature, London 162, 779.
Nagarajan, S., Ganem, B. \& Pegg, A. E. (1988). Studies of nonmetabolizable polyamines that support growth of SV-3T3 cells depleted of natural polyamines by exposure to $\alpha$-difluoromethylornithine. Biochemical Journal 254, 373-378.

Pfaller, M. A., Riley, J. \& Gerarden, T. (1988). Polyamine depletion and growth inhibition in Candida albicans and Candida tropicalis by $\alpha$-difluoromethylornithine and cyclohexylamine. Journal of Medical and Veterinary Mycology 26, 119-126.

Porta, R., Camardella, M., DeSantis, A., Gentile, V. \& SelLINGER, O. Z. (1983). Polyamines and methionine sulfoximineinduced seizures. Advances in Polyamine Research 4, 209-219.

Porter, C. W. \& BERgeron, R. J. (1988). Enzyme regulation as an approach to interference with polyamine biosynthesis - an alternative to enzyme inhibition. Advances in Enzyme Regulation 27, 57-79.

RAJAM, M. V.\& GALSTON, A. W. (1985). The effects of some polyamine biosynthetic inhibitors on growth and morphology of phytopathogenic fungi. Plant and Cell Physiology 26, 683-692.

RajaM, M. V., Weinstein, L. H. \& Galston, A. W. (1989). Inhibition of uredospore germination and germ tube growth by inhibitors of polyamine metabolism in Uromyces phaseoli L. Plant and Cell Physiology 30, 37-41.

Sarhan, S., Dezeure, F. \& SeIler, N. (1987). Putrescine derivatives as substrates of spermidine synthase. International Journal of Biochemistry 19, 1037-1047.

Seiler, N., Knödgen, B., Bink, G., Sarhan, S. \& Bolkenius, F. (1983). Diamine oxidase and polyamine catabolism. Advances in Polyamine Research 4, 135-154.

Shapira, R., Altman, A., Henis, Y. \& Chet, I. (1989). Polyamines and ornithine decarboxylase activity during growth and differentiation in Sclerotium rolfsii. Journal of General Microbiology 135, 1361-1367.

Shirahata, A., Morohoshi, T. \& Samejima, K. (1988). Trans-4methylcyclohexylamine, a potent new inhibitor of spermidine synthase. Chemical and Pharmaceutical Bulletin 36, 3220-3222.

Smith, T. A. \& Marshall, J. H. A. (1988). The oxidative decarboxylation of ornithine by extracts of higher plants. Phytochemistry 27, 703-710.

SMith, T. A., BarKeR, J. H. A. \& JunG, M. (1990). Effect of enzymeactivated inhibitors on ornithine decarboxylase and growth of Botrytis cinerea. Phytochemistry 29 (in the Press).

Stevens, L. \& McKinnon, I. M. (1977). The effect of 1,4diaminobutanone on the stability of ornithine decarboxylase from Aspergillus nidulans. Biochemical Journal 166, 635-637.

TABOR, H., TABOR, C. W. \& DE MEIS, L. (1971). Chemical synthesis of $N$-acetyl-1,4-diaminobutane, $N^{1}$-acetylspermidine, and $N^{8}$-acetylspermidine. Methods in Enzymology 17B, 829-833.

TAN, K. K. \& EPTON, H. A. S. (1973). Effect of light on the growth and sporulation of Botrytis cinerea. Transactions of the British Mycological Society 61, 147-157.

Trione, E. J., Stockwell, V. O. \& Austin, H. A. (1988). The effects of polyamines on the growth and development of the wheat bunt fungi. Botanical Gazette 149, 173-178.

Tyms, A. S., Williamson, J. D. \& Bacchi, C. J. (1988). Polyamine inhibitors in antimicrobial chemotherapy. Journal of Antimicrobial Chemotherapy 22, 403-427.

Weinstein, L. H. \& Galston, A. W. (1988). Prevention of a plant disease by specific inhibition of fungal polyamine biosynthesis. International Publication no. WO 88/02986 (Chemical Abstracts 109, $106548)$.

WaLters, D. (1989). Polyamines and plant disease. Plants Today (JanFeb 1989), 22-26. 